\title{
The son of man: "Is it constructive theology and history of Jesus for the New Testament writing?"
}

\author{
Halim Wiryadinata \\ Faculty of Theology, STT Pelita Bangsa \\ halimwiryadinata@sttpb.ac.id
}

\begin{tabular}{|c|c|}
\hline Article Info & Abstract \\
\hline Submitted: & Many scholars and lay people try to figure out the reasons why the Lord Jesus \\
\hline June 16,2020 & Christ uses the title of the son of man to designate Himself. He uses the title of \\
\hline Review Start: & the son of man throughout the Gospels, but there are some incidents only \\
\hline June 23,2020 & appear outside of the Gospels. This appearance is impressing to find out the \\
\hline Accepted: & reasons why the term occurrences in the Gospel. However, the term also \\
\hline Sept 2, 2020 & $\begin{array}{l}\text { appears in few passages outside the Gospels. Therefore, using the method of } \\
\text { critical analysis through the library research as the qualitative methodology in }\end{array}$ \\
\hline Keyv & $\begin{array}{l}\text { order to seek the development of the argument from beginning up today and to } \\
\text { see how the New Testament scholars clear up the message of Jesus in using }\end{array}$ \\
\hline Son of Man & that title. Few scholars comment that term has significant for the Christological \\
\hline representative, High & development of the New Testament due to the messianic proclamation as the \\
\hline Priest, man, God. & $\begin{array}{l}\text { saviour of the world. Furthermore, the idea of representative between man and } \\
\text { God apparently introduces the idea of the high priest in the New Testament } \\
\text { writing for Jesus' Christology. This idea will bring the consumption for Biblical } \\
\text { Theology when scholars seek this terminology in the New Testament writing. }\end{array}$ \\
\hline
\end{tabular}




\section{INTRODUCTION}

$\mathrm{I}$ $t$ is remarkably interesting to explore the terminology that the Bible uses for the purpose of the theology in God's means. It also assumes that the terminology, which the Bible uses for, will have an implication for the rest of theology in the Bible. In other words, the terminology is particularly important for the purpose of the Bible. If this is so, then the terminology of the son of man will be essential for the theology of both Testaments. The interesting fact is that the Lord Jesus Christ Himself says that he is the son of man in the Gospels almost 67 occurrences, according to the Bibleworks, throughout the Gospels. Therefore, the questions arise: What is the significance of the son of man for the Jesus Christ himself? Why does the Lord Jesus Christ favor saying that $\mathrm{He}$ is the son of man than he is the Son of God? Is there an important implication of the terminology for the Christian Theology?

Lourie (2015) sees that the apocalyptic of synoptic Gospels represents the idea of Passover. ${ }^{1}$ While, Ginsberg (2013) sees that the son of man associates with the suffering servant of Messiah. ${ }^{2}$ Then, this leads Cullmann to see that the son of man links to His death and to picture the ebed Yahweh. ${ }^{3}$ In other words, the idea of the son of man brings the concept of ransom in Mark 15: 45, where it alludes to the soffering for $\sin$ in Isaiah 53: 10. Therefore, this position is stood for the conservative view of Jesus' use the son of man terminology. ${ }^{4}$ However, we shall investigate the idea of conservative position in the Gospel of Mark in 10: 45, the Lord Jesus Christ says, "For the son of man did not come to be served, but to serve, and to give as a ransom for many."

Some scholars, furthermore, see that the picture of this verse is referring that the Lord Jesus Christ is the servant of the Lord. If this verse gives the picture of being a servant, then the son of man will seem have a concept of being servant too. This picture seems to be explored in order to get the real message of the son of man's mean. Therefore, I would like to argue that the son of man terminology appears to introduce the idea of Jesus as the High Priest in the letter of Hebrews, so the idea of the High Priest will not jump in the book of the New Testament writers, but it is as an introduction to see that Jesus as the High Priest after the order of Melchizedek. By doing so, I would like to divide three mainstreams: Firstly, to consider thoroughly the terminology beyond Pre-Christian Jewish Thought. Scondly, to analyse the term in the backdoor of the Old Testament and Pseudigripha. Finally, to ponder how the New Testament creates the idea of the son of man to camouflage of being representative between God and man in the form of the High Priest.

\section{METHOD}

\footnotetext{
${ }^{1}$ Basil Lourié, “The 'Synoptic Apocalypse' (Mt 24-25 Par.) and Its Jewish Source,” Journal of Patrology and Critical Hagiography 11, no. 1 (2015): 87-108, https://doi.org/10.1163/1817756500111 p11.

${ }^{2}$ H. L. Ginsberg, "The Oldest Interpretation of the Suffering Servant," Vetus Testamentum 63, no. 10 (2013): 25-28, https://doi.org/10.1163/15685330-99000005.

${ }^{3}$ Oscar Cullmann, The Christology of the New Testament (Philadelphia: The Westminster Press, 1963)., 65.

${ }^{4}$ Lourié, "The 'Synoptic Apocalypse' (Mt 24-25 Par.) and Its Jewish Source."

${ }^{5}$ George E. Ladd, A Theology of the New Testament (Michigan: William B Eerdmans, 1993)., 154 -155 .
} 
The method to be used in this research takes the form of a critical analysis of the recent study, as a method of retrieving the main problems in the terminology of the son of man. By critical analysis is to perform the library research method to gain the perspective emic of the conceptual and theoretical facts through the development of the arguments of the New Testament scholars. ${ }^{6}$ Then, the research will develop the critical theory to influence the readers to have a new paradigm to look at the term of the son of man. As a result, this evaluation shall be restricted to the period of early Christology in order to get the main purpose of the idea of the son of man. By conducting this assessment, we shall find out to which extent of misunderstanding of the scholars at the door of Biblical Theology. In other words, the examination will be using the descriptive basis in order to get thelocus for expanding our argument to the main subject. It is expected that this shall enable us to put forward some ideas to get the answer of the research.

Furthermore, the approach of 'corporate identity' will be assumed throughout this research, because the the concept of Jesus as the high priest is for the whole mankind and the church herself. This, however, does not mean that the concept of personal identity is less significant to the research, but both personal and corporate identities certainly give the idea of the son of man grounded in the direction of the human existence. ${ }^{7}$ Thus, the composition of this study the background of the son of man from the early church history. From here the argument is developed through the critical analysis in looking for the possible picture of the answer. Finally, after finding at a possible solution in the terminology of the son of man, then the possible answer can be applied to the Biblical Theology.

\section{DISCUSSION}

\section{The Background of the son of man in Pre-Christian Jewish Thought}

Most modern treatments of the subject begin on the premise that there existed in pre - Christian Judaism a generally well - defined concept of a transcendent redeemer figure, spoken of as the son of man, whose coming to earth as Judge would be a feature of the drama of the End Time. The evidence for such a conception can be found in Daniel 7, 1 Enoch 37-71 and Iv Ezra 13. However, Richard Longenecker argues that there is a major difficulty for having the evidence for the pre-Christian nature of Book II of Ethiopic Enoch and it is precarious to deduce the existence of a firm Son of Man concept in the intertestimental period from Daniel 7 and IV Ezra 13. ${ }^{8}$ Richard Longenecker's view is supported by J. Y. Campbell when he says, "Most of extant manuscripts of the Ethiopic Enoch belong to the eighteenth century; none can be confidently dated earlier than the sixteenth."

If the guest of the Ethiopic Enoch had been translated in the sixth or seventh centuries, then it should be removed from the pre-Christian times. C. H. Dodd (1952) insists strongly when

${ }^{6}$ Amir Hamzah, Metode Penelitian Kepustakaan (Malang: Literasi Nusantara, 2020); Mestika Zed, Metode Penelitian Kepustakaan (Jakarta: Yayasan obor Indonesia, 2004).

${ }^{7}$ Halim Wiryadinata, "An Analysis of Economic Wealth of God's People from Nomadic to Post Exilic Era,” DUNAMIS: Jurnal Teologi Dan Pendidikan Kristiani 3, no. 2 (2019): 155, https://doi.org/10.30648/dun.v3i2.184.

${ }^{8}$ Richard N Longenecker, "Son of Man as A Self - Designation of Jesus," Journal of the Evangelical Society 12, no. 3 (1969): 151-63.

9 J. Y Campbell, "The Origin and Meaning of the Term of Son of Man," Journal of Theological Studies 191, no. 2 (1947)., 146. 
he refuses to erect any arguments on evidence drawn from the Similitudes. ${ }^{10}$ This point also is supported by R. H. Fuller when he says, "While...we cannot be sure that the Similitude themselves antedate the Christian era, we may treat them with some degree of confidence as evidence for a tradition in Jewish apocalyptic which is pre - Christian. ${ }^{11}$ In other words, it argues that since it cannot be definitely proved that they are not pre - Christian, we may continue to use them as such. According to Richard N Longenecker (1969), the three alleged sources (I Enoch 37-71, IV Ezra 13 and Daniel 7), only Daniel 7 is demonstrably pre - Christian; IV Ezra, written by a quietist Pharisee, almost certainly stems from the latter part of the first Christian century and the Similitudes of Enoch was probably written about the same time, or even later, possibly by a Jewish Christian with roots of some type in Jewish Essenism. ${ }^{12}$

C. H. Dodd argues very well when he sees that there are three passages in the Scripture containing the term of Son of Man and three of them can be proved to have been employed for testimonies to elucidate the New Testament: Psalm 8, Psalm 80 and Daniel 7. ${ }^{13}$ This argument is backed up by Alan Richardson when he sees that the recurrent Son of Man expression in Ezekiel is not the basic passage, which contains the Messianic title. ${ }^{14}$ This makes C. H. Dodd (1952) also sees "Ezekiel may no doubt have in the minds of early Christians, ...proof that it was so is lacking in the New Testament. Ezekiel does not appear to have been a primary source of testimonies." 15

Christian scholars only have sole dependence upon Daniel in understanding the title in the pre - Christian thought. This makes people unable to continue to interpret the seemingly enigmatic figure of Daniel 7 by the categories of I Enoch 37 - 71. Most scholars emphasize that Daniel 7, the one like a Son of Man, is claimed as a messianic and exalted redeemer figure through all sufferings. C. F. D. Moule sees the book of Daniel 7: 21, 25, especially aggressive 'horn' on the beast's head, pointing out the war of the saints by wearing the robe as the saints of the most high, where the son of man is identified as the most High. ${ }^{16}$ Then, Moule goes to insist that the interpretation of the son of man is less important, because all the followers of Jesus and the discipleship look at Daniel 7 is more important than elsewhere. The idea of Jesus'suffering is not bothered among the followers of Jesus and the disciples due to the glorification of Jesus as the son of God.. ${ }^{17}$ If C. F. D. Moule is right in his assumption, then I would suggest that there are two connotation contained in the title Son of Man in pre - Christian Jewish thought: humility and suffering and majesty and glory.

\section{The son of man: History, the Old Testament, and Pseudigrapha}

The idea of the terminology of the son of man comes first time in the book of Daniel 7: 13- 14. The verses 13-14 of Daniel chapter 7 says, "In my vision at night I looked and there before me

${ }^{10}$ C. H. Dodd, According to the Scriptures (London: Nisbet, 1952)., 116 - 177.

${ }^{11}$ R. H Fuller, Foundations of New Testament Christology (Collins: Fontana Library of Theology and Philosophy, 1969)., 37 - 39. Cf. M. D. Hooker, "R. H. Fuller, The Foundations of New Testament Christology," Religious Studies 7, no. 3 (1971): 288-89, https://doi.org/10.1017/s0034412500002262.

${ }^{12}$ Longenecker, "Son of Man as A Self - Designation of Jesus.", 153.

${ }_{13}^{13}$ Dodd, According to the Scriptures., 20-21.

${ }^{14}$ Alan Richardson, An Introduction to the Theology of the New Testament (London: SCM Press, 1958)., $20-21$.

${ }^{15}$ Dodd, According to the Scriptures., 117.

${ }^{16}$ C. F.D. Moule, “"The son of man': Some of the Facts,” New Testament Studies 41, no. 2 (1995): 277-279., 178.

${ }^{17}$ Moule. 
was one like a son of man, coming with the clouds of heaven. He approached the Ancient of Days and was led into his presence. He was given power, glory and sovereign authority; all peoples, nations and men of every language worshiped him. His dominion is an everlasting dominion that will not pass away, and his kingdom is one that will never be destroyed." However, the terminology appears in the saying of the Lord Jesus Christ throughout His Gospels and there is one exception, which is used by Stephen in Acts 7: 56 when he called out: "I see the heavens opened, he said, and the son of man standing at the right hand of God." Apart from that, we can see the quotation of the son of man appears in Heb. 2: 6 (quoting Psalm 8: 5) and Revelation 1: 3, 14: 14 (alluding to Dan 7: 13). Therefore, the question should come up: What does it mean when the Lord Jesus Christ calls Himself as the son of man? Does it have an implication for the New Testament theology?

In the light of F. F. Bruce, he says that the meaning of the son of man' terminology, means literally a 'man'. ${ }^{18}$ This is so, because he explores that the Lord Jesus Christ normally says the son of man in Aramaic and the expression of it means literally 'a man'. The terminology of the son of man by the Lord Jesus Christ does not mean a literally to designate 'I myself", but it is rather a broader context. He takes an example from Mark 2: 10 when it says that "The son of man has authority on earth to forgive sins." Bruce comments strongly that Jesus was exercised this authority in his own person, but when he claimed to exercise it as the son of man, the phrase may mean something like the representative man. ${ }^{19}$

On the other side, Petr Pokorny and Allison et.al sees the function of the son of man is becoming the eschatological ruler and judge. ${ }^{20}$ This is so, because he sees the parallelism between the Gospels (especially Mark 12: 36f) and Psalm 110: 1 pointing to the installation as the eschatological king in Daniel 7: 13f. Therefore, it makes F. F Bruce sees that the terminology of the son of man, in the light of the Gospels, seems to point the suffering of the son of man for the investment of glory for the latter action. ${ }^{21} \mathrm{He}$ assumes that Daniel's vision of 'one like a son of man', which is in Aramaic, is enthroned alongside the Ancient of Days and it has a link with the oracle of Psalm 110: 1 that calls 'my lord' to sit at the right hand of God. According to William Scott Green, he sees that the terminology of the son of man has an associate with 1 Enoch 37 71 where he assumes there is a conflation of enthronement traditions. William insists that the first Enoch chapters $37-71$ have three points, which are the earthly king, the suffering and the exalted servant of YHWH. ${ }^{22}$ However, I would like to ask: what is the significance of the son of man in the light of the Gospel?

Howard Marshall sees the terminology of the son of man is not a title but rather a selfdesignation used in certain of contexts. ${ }^{23}$ The idea of Howard Marshall follows the arguments of Lindars when he points out the terminology of the son of man has a particular designation to

${ }^{18}$ F. F. Bruce, The Real Jesus (London: Hodder and Stoughton, 1985)., 58 - 59.

${ }^{19}$ Bruce., 61.

${ }^{20}$ Petr Pokorny, The Genesis of Christology (Berlin: Evangelische Verlagsanstalt GmbH, 1985)., 81. Dale C. Allison and Delbert Burkett, "The son of man Debate: A History and Evaluation," Journal of Biblical Literature (2000).

${ }^{21}$ Bruce, The Real Jesus., $81-82$.

${ }^{22}$ William S Green, Dictionary of Judaism in the Biblical Period (Massachuttes: Hendrickson Publishers, 1996)., $597-598$

${ }^{23}$ I. Howard Marshall, "The son of man," in Dictionary of Jesus and the Gospels, ed. I Marshall Green, Joel B , McKnight Scott, and Howard (Leicester: IVP, 1992)., 781. 
which the speaker belongs. Therefore, Marshall insists strongly that the idea of the son of man, which the Lord Jesus Christ uses, has a significant role for the Lord Jesus Christ in order to show that He should follow the role in Daniel $7 .{ }^{24}$ In other words, the terminology of the son of man shows the dignity of the Lord Jesus Christ. ${ }^{25}$ However, the question is prompted to be asked: what dignity is the Lord Jesus Christ to show for us and the entire Bible particularly theology of both testaments?

J. H. Charlesworth comments also the terminology in the light of the Pseudigrapha when he sees that 1 Enoch 37-71 is the major transformation in the book of Daniel. ${ }^{26} \mathrm{He}$ insists that repeatedly the specialists on 1 Enoch have come out in the favour of the Jewish nature of this section of 1 Enoch, and its first century C.E. origin and probable pre-70 date. The list of specialists on 1 Enoch arguing for this position has become overwhelmingly impressive: Isaac, Nicklesburg and no specialist now argues that 1 Enoch $37-71$ is Christian and postdates the first century. If $\mathbf{J}$ $\mathrm{H}$ Charlesworth sees that 1 Enoch $37-51$ is not a tradition for Christian literature, then the question arises: Are there any evidence to support the terminology 'The son of man'? The terminology 'The son of man' comes from the Aram language bar enash, which is especially important for Daniel 7.

Ben Witherington assumes that Daniel 7 has a clear allusion to the New Testament cititation. ${ }^{27} \mathrm{He}$ says there are 3 views that can be concluded in viewing the terminology of The son of man. Firstly, the figures refers to one or more angels; secondly, it is the symbol for the true Israel who endures the persecution; thirdly, it does not represent much on Israel, but Israel in the presence of God Almighty ${ }^{28}$ From his discussion, the third view is more plausible when he comes along the argument of Casey when Casey says that it is not that the man-like figure has independent experiences; he is a pure symbol with no experience at all, other than the symbolic ones in vv. 13-14. To that extent he is separate figure and he is to be disassociated from the suffering of the Saints. ${ }^{29}$ However, Witherington argues that it is not merely symbol, but it should be an individual in the light of the Enochian literature. He comes to conclusion that Daniel 7 is the apocalyptic language for the experience individual who is the representative of and for Israel. ${ }^{30}$

If this is so, then the figure should be the representative for the people when they come to the Most High. Therefore, the Old Testament background of being representative is very dominant in Daniel 7.

\section{The Background of the son of man and Its Teachings in the New Testament}

The term of 'The son of man' is very fascinating in the New Testament era, because this term comes up in the area of the Gospels. Only few occurrences of the term appear outside of the Gospels. George Eldon Ladd points out there are 3 distinct categories about the son of man in the

${ }^{24}$ Marshall., 788.

25 Alison G. Salvesen, “The Solution to the 'Son of Man' Problem," Journal of Jewish Studies, 2013, https://doi.org/10.18647/3127/jjs-2013.

${ }^{26}$ J. H. Charlesworth, The Old Testament Pseudigrapha and the New Testament (Cambridge: Cambridge University Press, 1984)., 89.

${ }^{27}$ Ben. Witherington, The Christology of Jesus (Minneapolis: Fortress Press, 1990).

${ }^{28}$ Witherington.

${ }^{29}$ M. Casey, Son of Man: The Interpretation and Influence of Daniel 7 (London: SPCK, 1979)., 240.

${ }^{30}$ E. Joshua. Leim, "In the Glory of His Father: Intertextuality and Apocalyptic Son of Man in the Gospel of Mark,” Journal of Theological Interpretation 7, no. 2 (2013): 213-32. 
background of the New Testament. They are the son of man on earth serving; the son of man in suffering and the son of man in eschatological glory. ${ }^{31}$ Ladd explains that the concept of the ebed Yahweh in the Isaiah 53 is the background of the suffering the son of man. He is supported by Black when it says that the son of man is not only heavenly, pre-existent being; he appears in weakness and humility as a man among human beings to fulfil a destiny of suffering and death. In other words, Jesus poured the content of the suffering Servant into the son of man concept. ${ }^{32}$

If Black's presupposition is right, then the concept of ransom in Mark 10: 45 alludes to the offering for $\sin$ in Isaiah 53: 10. Therefore, the redemption is going to be in the mind of the Jesus while His serving on earth. ${ }^{33}$ This leads people to see the idea of messianic in the New Testament area in the terminology of the son of man. ${ }^{34}$ However, the question comes up: What messianic idea is it? Is there a replacement idea of the son of man in the New Testament concept?

The title Son of Man occurs 81 times in the Gospels, 67 of them in the Synoptic Gospels. All of the occurrences are attributed to Jesus Himself. In no instances is the title recorded as given to Jesus by others, nor is it employed in any explanatory manner by the evangelists themselves. Apart from the Gospels, the title also appears only in the quotation of Psalm 8:4-6 in Hebrews 2: $6-8$, on the lips of the dying Stephen in Acts 7: 56 and in the parabolic description of the exalted Jesus in the book of Revelation 1: 13 and 14: 14. In other words, this is only in the latter three cases (Acts 7: 56 and Revelation 1: 13, 14: 14), however, that it is employed as a Christological title outside of the Gospels. Therefore, it would seem that there is a widely based tradition that Jesus used the term of Himself and little evidence that there was any extensive use of Son of Man as a Christological title on the part of Christians during the first century. ${ }^{35}$

In the Gospel tradition, the term Son of Man is the favourite way of Jesus designating Himself and He uses it freely. In other words, the title has never used anyone else in the New Testament to designate Jesus the Christ. ${ }^{36}$ Even there is no evidence at all in the early Church using the title in Acts and the Epistles and the title also never becomes a messianic designation for Jesus in the early Church. However, the New Testament scholar, G. Dalman, argues that the title seems not to be famous and common; it could be used as a messianic designation. ${ }^{37}$

Another objection to the Gospels concerning the term Son of Man is that the title does not exist in Aramaic and the Greek expression ho huios tou anthropou is actually translation from the Aramaic bar anasa. In other words, the term itself means nothing more than 'man' ${ }^{38}$ It is true from the Old Testament "God is not a man, that he should lie, or a son of man, that he should repent" (Numbers 23: 19) and "O Lord, what is man that you care of him, or the son of man that

${ }^{31}$ Ladd, A Theology of the New Testament., $147 \mathrm{ff}$.

${ }^{32}$ Matthew Black, "Servant of the Lord and Son of Man," Scottish Journal of Theology 6, no. 1 (1953): 1-11, https://doi.org/10.1017/S0036930600005305.

33 Philip R Davies, "Dualism and Echatology," Brill 30, no. 1 (1980): 93-97.

${ }^{34}$ John Ashton, "The Johannine Son of Man: A New Proposal," New Testament Studies, 2011, https://doi.org/10.1017/S0028688511000178.

${ }^{35}$ Christar Arstilo Rumbay, "Christology in Digital Era: A Socio-Systematic Theology

Contribution to the Sustainable Smart City," Pasca Journal 6, no. 2 (2020): 15-23, https://doi.org/https://doi.org/10.46494/psc.v16i1.70.

36 John J Collins, “Apocalyptic Genre and Mythic Allusions in Daniel,” JSOT 21 (1981): 83-100.

${ }^{37}$ G Dalman, The Word of Jesus (London: SCM Press, 1909).

${ }^{38}$ Ginsberg, "The Oldest Interpretation of the Suffering Servant." 
you think of him?" (Psalm 144: 3) ${ }^{39}$ Therefore, it seems strange if the linguistic argument holds any weight, that the expression is never used elsewhere in the Gospels as an explanation for humanity. This argument also is abandoned by Dalman when he sees that Son of Man could be a messianic title has been widely accepted in contemporary biblical scholarship.

Looking at the title in Hebrews 2: $6-8$ (quotation from Psalm 8: $4-6$ ) and on the lips of the dying Stephen in Acts 7:56 and in the parabolic description of the exalted Jesus in the book of Revelation 1: 13 and 14: 14, actually creates the figuratively on the idea of being representative of mankind. Put in the different way, the idea of representative for mankind is conveying message of Jesus when He designates Himself as the son of man to be the representative between man and God and it refers to the High Priest as being representative for man and God. ${ }^{40}$ The allusion of it in the book of Revelation is the High Priest, because the person who dresses in a robe reaching down to his feet and with the golden sash round his chest. Therefore, it is wise to say that the title of the son of man gives the idea of representative and introducing the title of the high priest.

\section{Conclusion}

The debating on the title of Jesus as the son of man has shifted the paradigm from the conservative position to stand on the idea of servant of God, but the recent study, as I argue, that the title of the son of man introduces the idea of the high priest as the representative between man and God. The development of arguments from the beginning among the New Testament scholars has moved the idea of the servant of God, who died for many as ransom, to the idea of representative between man and God in the idea of the high priest as the introductory for the bigger theme of Jesus as the High Priest in the Biblical Theology.

The constructive theology and history of the son of man brings the theme, as the incarnated God, of Jesus as the High Priest for the representative between God and man. Here may the reason beyond the title of the son of man does not appear outside of the Gospels (except as I mentioned above) due to the introductory of the big theme of the High Priest after the order of Melchizedek. Jesus, as the incarnated of God, will be shown as the Saviour for the people to God.

\section{REFERENCE}

Allison, Dale C., and Delbert Burkett. "The Son of Man Debate: A History and Evaluation." Journal of Biblical Literature, 2000. https://doi.org/10.2307/3268537.

Ashton, John. "The Johannine Son of Man: A New Proposal.” New Testament Studies, 2011. https://doi.org/10.1017/S0028688511000178.

Black, Matthew. "Servant of the Lord and Son of Man." Scottish Journal of Theology 6, no. 1 (1953): 1-11. https://doi.org/10.1017/S0036930600005305.

Bruce, F. F. The Real Jesus. London: Hodder and Stoughton, 1985.

Campbell, J. Y. "The Origin and Meaning of the Term of Son of Man." Journal of Theological Studies 191, no. 2 (1947).

${ }^{39}$ U Luz, "The son of man in Matthew: Heavenly Judge or Human Christ," JSNT 3, no. 21 (1992):

${ }^{40}$ Marius Nel, “'Son of Man' in the Gospel of Mark,” In Die Skriflig / In Luce Verbi 51, no. 3 (2017): 1-9, https://doi.org/10.4102/ids.v51i3.2096. 
Casey, M. Son of Man: The Interpretation and Influence of Daniel 7. London: SPCK, 1979.

Charlesworth, J. H. The Old Testament Pseudigrapha and the New Testament. Cambridge: Cambridge University Press, 1984.

Collins, John J. "Apocalyptic Genre and Mythic Allusions in Daniel.” JSOT 21 (1981): 83-100.

Cullmann, Oscar. The Christology of the New Testament. Philadelphia: The Westminster Press, 1963.

Dalman, G. The Word of Jesus. London: SCM Press, 1909.

Davies, Philip R. "Dualism and Echatology." Brill 30, no. 1 (1980): 93-97.

Dodd, C. H. According to the Scriptures. London: Nisbet, 1952.

Fuller, R. H. Foundations of New Testament Christology. Collins: Fontana Library of Theology and Philosophy, 1969.

Ginsberg, H. L. "The Oldest Interpretation of the Suffering Servant." Vetus Testamentum 63, no. 10 (2013): 25-28. https://doi.org/10.1163/15685330-99000005.

Green, William S. Dictionary of Judaism in the Biblical Period. Massachuttes: Hendrickson Publishers, 1996.

Hamzah, Amir. Metode Penelitian Kepustakaan. Malang: Literasi Nusantara, 2020.

Hooker, M. D. "R. H. Fuller, The Foundations of New Testament Christology." Religious Studies 7, no. 3 (1971): 288-89. https://doi.org/10.1017/s0034412500002262.

Ladd, George E. A Theology of the New Testament. Michigan: William B Eerdmans, 1993.

Leim, E. Joshua. "In the Glory of His Father: Intertextuality and Apocalyptic Son of Man in the Gospel of Mark." Journal of Theological Interpretation 7, no. 2 (2013): 213-32.

Longenecker, Richard N. "Son of Man as A Self - Designation of Jesus." Journal of the Evangelical Society 12, no. 3 (1969): 151-63.

Lourié, Basil. "The 'Synoptic Apocalypse' (Mt 24-25 Par.) and Its Jewish Source.” Journal of Patrology and Critical Hagiography 11, no. 1 (2015): 87-108. https://doi.org/10.1163/18177565-00111p11.

Luz, U. "The Son of Man in Matthew: Heavenly Judge or Human Christ.” JSNT 3, no. 21 (1992): 3-20.

Marshall, I. Howard. "The Son of Man.” In Dictionary of Jesus and the Gospels, edited by I Marshall Green, Joel B , McKnight Scott, and Howard. Leicester: IVP, 1992.

Moule, C. F.D. “'The Son of Man': Some of the Facts.” New Testament Studies 41, no. 2 (1995): 277-79. https://doi.org/10.1017/S0028688500021287.

Nel, Marius. "'Son of Man' in the Gospel of Mark.” In Die Skriflig / In Luce Verbi 51, no. 3 (2017): 1-9. https://doi.org/10.4102/ids.v51i3.2096.

Pokorny, Petr. The Genesis of Christology. Berlin: Evangelische Verlagsanstalt GmbH, 1985.

Richardson, Alan. An Introduction to the Theology of the New Testament. London: SCM Press, 1958.

Rumbay, Christar Arstilo. "Christology in Digital Era: A Socio-Systematic Theology Contribution to the Sustainable Smart City." Pasca Journal 6, no. 2 (2020): 15-23. https://doi.org/https://doi.org/10.46494/psc.v16i1.70.

Salvesen, Alison G. "The Solution to the 'Son of Man' Problem." Journal of Jewish Studies, 2013. https://doi.org/10.18647/3127/jjs-2013.

Wiryadinata, Halim. "An Analysis of Economic Wealth of God's People from Nomadic to Post Exilic Era.” DUNAMIS: Jurnal Teologi Dan Pendidikan Kristiani 3, no. 2 (2019): 155. https://doi.org/10.30648/dun.v3i2.184.

Witherington, Ben. The Christology of Jesus. Minneapolis: Fortress Press, 1990.

Zed, Mestika. Metode Penelitian Kepustakaan. Jakarta: Yayasan obor Indonesia, 2004. 